\title{
Vegetative propagation of an ornamental conifer: some techniques in podocarpo cutting
}

\section{Fernanda Jaqueline Menegusso ${ }^{1}$ (D) Fabíola Villa ${ }^{1^{*}}$ (D) Daniel Fernandes da Silva ${ }^{1}$ (D) Luciana Sabini da Silva ${ }^{1}$ (D) Giovana Ritter $^{1}$ (D) Tatiane Eberling ${ }^{1}$ (D)}

${ }^{1}$ Programa de Pós-graduação em Agronomia, Universidade Estadual do Oeste do Paraná (Unioeste), 85960-000, Marechal Cândido Rondon, PR, Brasil. E-mail: fvilla2003@hotmail.com."Corresponding author.

ABSTRACT: The asexual propagation of conifers, such as Podocarpus macrophyllus (Thunb.) Sweet, faces difficulties. Among the factors that can improve the efficiency of asexual propagation are the types of cuttings used and lesions performed at the base of the cuttings, and the use of plant regulators, such as indolebutyric acid (IBA). This study determined the types of lesions to be performed at the cutting base, the type of cuttings used, the method to convey IBA at the cutting base, and the concentration of IBA required to obtain a proper rooting condition for the species. Two experiments were performed from March to July, 2018, in randomized blocks and with a factorial scheme, as follows: $2 x$ 4 (IBA application in solution and talc $x$ IBA at concentrations of 0, 500, 1,000, and 1,500 $\mathrm{mg} \mathrm{L}^{-1}$ IBA); and $2 \times 3$ (basal and apical cuttings $x$ bevel, wedge, and horizontal lesions at the cutting base). In both experiments, the cuttings used were arranged on a masonry bed containing medium-textured sand. After 120 days of experimentation, the study concluded that the rooting percentage was favored by the use of basal cuttings with wedge lesions at the cutting base and treated with IBA in solution at a concentration of approximately $550 \mathrm{mg} L^{-1}$.

Key words: Podocarpus macrophyllus (Thunb.) Sweet, asexual propagation, buddhist pine, rooting.

Propagação vegetativa de uma conífera ornamental: algumas técnicas no estaqueamento de podocarpo

RESUMO: A propagação assexuada de coniferas, como o Podocarpus macrophyllus, apresenta dificuldades. Entre os fatores que podem tornar mais eficientes a propagação assexuada tem-se o tipo da estaca utilizada, lesões na base da estaca e uso de fitoreguladores, como o ácido indolbutírico (AIB). Objetivou-se determinar o tipo de lesão a ser efetuado na base da estaca e o tipo de estaca bem como método de veiculação do AIB na base da estaca e a concentração do AIB visando obter melhor enraizamento para a espécie. Dois experimentos foram realizados, no período de março a julho de 2018, em blocos casualizados e esquema fatorial, sendo o primeiro $2 \times 4$ [aplicação AIB em solução e em talco x concentração de 0, 500, 1000 e $1500 \mathrm{mg} \mathrm{L}^{-1}$ de ácido indolbutírico (AIB)] e o segundo $2 \times 3$ [estaca basal e apical x lesões na base da estaca do tipo bisel, cunha e horizontal].Em ambos experimentos as estacas utilizadas foram dispostas em canteiro de alvenaria contendo areia de textura média. Após 120 dias de experimentação conclui-se que o uso de estacas basais com lesões na base da estaca em cunha e tratadas com AIB em solução na concentração de aproximadamente $550 \mathrm{~mL} \mathrm{~L} \mathrm{~L}^{-1}$ favorecem a porcentagem de enraizamento.

Palavras-chave: Podocarpus macrophyllus (Thunb.) Sweet, propagação assexuada, pinheiro de buda, enraizamento.

\section{INTRODUCTION}

The Podocarpaceae is composed of 18 genera and about 173 species of coniferous trees and shrubs. Plants of this family have simple, complete, alternate or subopposite, rarely opposite (Microcachrys Hook. f.), coriaceous, linear, lanceolate, acicular, oval, or scale-like leaves with whole margins. The seeds have fleshy external and woody internal teguments, and the embryo has two cotyledons (MARINHO et al., 2016). Among the species of interest belonging to this family, the Buddhist pine Podocarpus macrophyllus (Thunb.) Sweet (synonym: Taxus macrophylla Thunb.) stands out for its ornamental value and expressive use in landscaping. Sexual propagation of the species has some limitations, such as difficulty in obtaining seeds. This leads to non-uniformity in the achievement of seedlings and is in line with the fact that conifers are often characterized by great longevity and a low potential rate of population increase compared with angiosperms, putting them at a competitive disadvantage. An alternative to circumvent these characteristics is asexual propagation by cutting (LORENZI \& SOUZA, 2013).

The asexual propagation of conifers such as $P$. macrophyllus faces challenges regarding rooting associated with the plant's maturation stage, a process that is age-related and affects reproductive competence, morphology, and growth rate (ENRIGHT 
\& JAFFRÉ, 2010; RAGONEZI et al., 2010). Another issue is related to functional restrictions in the growth rate resulting from a less efficient vascular system than that of angiosperms. In the vascular system of conifers, tracheids are usually more resistant to solute flow than angiosperms' vessels, and their leaves are not fully vascularized (ENRIGHT \& JAFFRÉ, 2010).

Among the factors that can make asexual propagation more efficient is the cutting type used (VILLA et al., 2017). The chemical composition from the base to the tip of a branch can differ, leading to dissimilarities among the use of basal, median, and apical cuttings (ZANÃO et al., 2016). Overall, the number of roots obtained from a cutting decrease from the basal to the apical parts of a branch, i.e., the rooting capacity of basal cuttings is greater than apical cuttings (VIEIRA NETO et al., 2011). Moreover, as the cutting base accumulates carbohydrates, root development will be favored (HARTMANN et al., 2018).

Regarding cuttings, the practice of performing lesions at the base may contribute to root formation because there is greater absorption of water and phytohormones, increasing the efficiency of rooting (SANTORO et al., 2010). Cell division is stimulated by the increased respiratory rate and auxin, carbohydrates, and ethylene levels in the injured area. In turn, the lesions allow the physical barrier formed by the sclerenchyma rings to be broken, which may even prevent root emergence (HOSSAIN et al., 2019; HUNT et al., 2011).

Another way to enhance the formation of the root system is to use plant regulators to induce the rhizogenic process and increase the percentage of cuttings forming roots, the number and quality of roots formed, and the uniformity in rooting (CIRIELLO et al., 2015; HUNT et al., 2011). Although, indolebutyric acid (IBA) is the most widely applied substance for this purpose, there are still issues in making specific recommendations for using this plant regulator (SALVADOR et al., 2014). Compared to other auxins of localized action, IBA is also photostable, persistent, non-toxic at a wide range of concentrations, not degraded by biological action, and has little mobile in the cutting, thus remaining longer at the application site (CORDEIRO et al., 2016). Besides, it can be applied in a liquid or powder form (YAMAMOTO et al., 2010).

The vegetative parts (foliage) and potted plants of $P$. macrophyllus have great importance in the ornamental plant sector and are widely sold in Veiling (Holambra, São Paulo state, Brazil) and grown in gardens in several Brazilian states. However, its propagation for seedling production is still unknown (PROPLANT,
2012; TOGNON \& CUQUEL, 2015). In this context, this study improved the techniques used in rooting $P$. Macrophyllus cuttings by evaluating the lesion type to be performed at the cutting base and the cutting type, as well as the method of propagation of IBA at the cutting base and the most effective IBA concentration.

\section{MATERIALS AND METHODS}

Experiments were carried out from March to July, 2018, both of which were developed at the Professor Doutor Mário Cesar Lopes Protected Cultivation and Biological Control Station, belonging to the Protected Cultivation and Horticulture Experimental Station of Unioeste, Marechal Cândido Rondon Campus, Paraná state, Brazil (243'22”S, $54^{\circ} 03^{\prime} 24^{\prime \prime} \mathrm{W}$; approximate altitude of $420 \mathrm{~m}$. The experiments were conducted under $50 \%$ shading roof conditions. The three-year-old parent plants used for removing the cuttings were derived from asexual propagation; they were purchased from an ornamental plant producer in the municipality of Marechal Cândido Rondon. The $1.2 \mathrm{~m}$ tall parent plants were transplanted into $12 \mathrm{~L}$ polyethylene pots containing a mixture of latosol, washed sand, and organic matter (1:1:1, v/v/v)as a substrate and were acclimatized in the shade for 90 days before being used in the experiments.

The visual control of pests and diseases was performed weekly, both on the parent plants and removed cuttings. Whenever necessary, agricultural pesticides were applied. The visual control of cochineals was performed during the experimental period using the commercial product Chlorpyrifos Fersol 480 EC $(150 \mathrm{ml} / 100 \mathrm{~L}$ water; chlorpyrifos as the active ingredient) + mineral oil $(1 \mathrm{~L} / 100$ $\mathrm{L}$ water). Irrigation was performed daily using a sprinkler irrigation system activated for $5 \mathrm{~min}$ and 1 $h$ average intervals, with a flow rate of $1.17 \times 10-8 \mathrm{~m}^{3}$ $\mathrm{s}^{-1}$. The average temperature during the experiment was $22.4{ }^{\circ} \mathrm{C}$, and the relative humidity was $73.14 \%$. The IBA used in the first experiment was weighed in a precision balance and diluted in $0.1 \mathrm{~L}$ of ethanol hydrated at $46.2^{\circ}$ INPM (Brazil's Institute of Weights and Measures); then, $0.1 \mathrm{~L}$ of distilled water was added, resulting in $0.2 \mathrm{~L}$ of the final concentrations (500, 1,000, and 1,500 $\left.\mathrm{mg} \mathrm{L}^{-1}\right)$. Toprepare IBA in talc, the amount corresponding to each concentration was mixed in commercial talc (Plastofibras ${ }^{\circledR}$ ) until $100 \mathrm{~g}$ of the product was achieved. For better homogenization, ethanol was added to form a paste; this mixture was then transferred to an oven at $40{ }^{\circ} \mathrm{C}$, where it remained until the solvent evaporated. 
Branches were removed from the parent plants with pruning shears along the entire length of the plant, i.e., from different plant heights. The $10 \mathrm{~cm}$ long cuttings were prepared from these branches by discarding the apical part; four leaves were kept per cutting and were used in the first experiment. The cutting base was dipped for $10 \mathrm{~s}$ in the prepared IBA solutions. For the control treatment (without IBA), the cutting bases were dipped in distilled water for 10 s. For those with talc, the base was placed in contact with the product for $15 \mathrm{~s}$ until it was well adhered. For the control treatment, the base was only left in contact with inert talc.

For the second experiment, the branches were removed from the parent plants as a whole. From these branches, cuttings of approximately $10 \mathrm{~cm}$ in length were prepared with the apical and basal parts, keeping four leaves per cutting. At the cutting base in experiment 2 , three lesion types were performed with a utility knife. Bevel lesions were performed with a diagonal cut, wedge lesions were done with a diagonal cut on each side of the cutting base, and horizontal lesions were performed with a straight cut perpendicular to the cutting.

In both experiments, immediately after being treated, the cuttings were arranged in a masonry bed containing washed sand of a medium texture. The sand was previously sterilized with $1 \mathrm{~L}$ of sodium hypochlorite diluted in $10 \mathrm{~L}$ of water, which was sprinkled over its entire area with a watering can. After 120 days, the percentage of rooted and calloused cuttings, number of roots, and length of the largest root $(\mathrm{cm})$ were evaluated for each experiment. Within each replicate containing 15 cuttings, five were randomly analyzed. These cuttings had the roots carefully washed in running water and dried with paper towels. For the variables involving percentages, counting performed and then the percentage was calculated. A graduated ruler was used for measuring the length of the largest root.

For the first experiment, the experimental design used was randomized blocks in a $2 \times 4$ factor scheme (application of IBA in solution and talc $\mathrm{x}$ IBA at concentrations of $0,500,1,000$, and $1,500 \mathrm{mg} \mathrm{L}^{-1}$ ), resulting in eight treatments. Three replicates and 15 cuttings per replicate were used, totaling 360 cuttings. In the second experiment, the experimental design used was randomized blocks in a $2 \times 3$ factor scheme (basal and apical cuttings $\mathrm{x}$ bevel and wedge lesions and control), resulting in six treatments containing three replicates and 15 cuttings per replicate, totaling 270 cuttings.

The means of the qualitative variables were submitted to an analysis of variance and were later compared by a Tukey's test, at a 5\% probability of error. The mean values of the quantitative variables were submitted to a regression analysis using the Sisvar software (FERREIRA, 2011).

\section{RESULTS AND DISCUSSION}

In the first experiment, the percentage of rooting was significant for the interaction of the IBA concentration $x$ IBA conveying methods, and the percentage of calloused cuttings was significant only for the IBA conveying method. The number and length of the roots were not significantly affected by the IBA concentrations and propagation method.

Regarding rooting, the immersion method increased the rooting percentage up to $78.29 \%$ at an IBA concentration of $550 \mathrm{mg} \mathrm{L}^{-1}$ (Figure 1). The use of talc to convey IBA did not significantly increase rooting. With talc, there may have been non-uniformity in the amount of powder adhered to the cutting, which may have affected rooting. This amount would be affected by moisture at the cutting base and the epidermis texture. There are indications that, in this conveying method, the concentrations of IBA used should be doubled. For example, if the best results are obtained with a solution of $1,000 \mathrm{mg}$ $\mathrm{L}^{-1}$ of IBA, then $2,000 \mathrm{mg} \mathrm{kg}^{-1}$ is necessary for using the powder form to overcome this non-uniformity (PEREIRA et al., 2015).

DOBNER et al. (2018) studied Cupressus lusitanica and Cryptomeria japonica, and reported that the use of IBA $\left(0-6,000 \mathrm{mg} \mathrm{L}^{-1}\right)$, in both a liquid medium and inert talc, was not efficient in inducing the rooting of cuttings obtained from adult trees of the two species. They suggested that possible phytotoxicity as a result of the concentrations used and the age of the parent plants (12 and 19 years old) were the cause.

The percentage of calloused cuttings was significantly affected by the IBA conveying method, and the use of talc resulted in lower values compared with the use of the solution (Table 1).

Cell multiplication is one of the stages for the formation of new adventitious roots during rhizogenesis, a characteristic that is also present in the development of calluses. Although, these are independent events, they can co-occur without a direct relationship. Therefore, callus formation is not a guarantee of root formation, with cuttings with a lower percentage of calluses preferred for forming roots (SILVA et al., 2015).

Of the variables analyzed in experiment 2 , the number of rooted cuttings was significant, for 


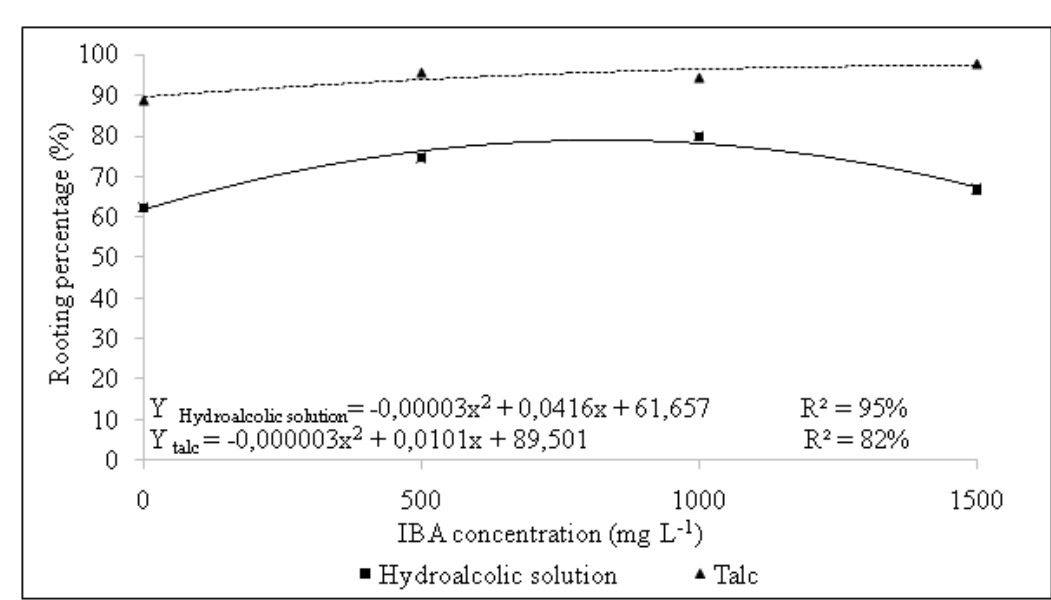

Figure 1 - Rooting percentage of podocarp cuttings with different concentrations of IBA in the form of hydroalcolic solution and talc.

which there was an interaction between the cutting type and the lesion type at the base. The rooting of base cuttings did not statistically differ among the lesion types at the cutting base, i.e., regardless of the lesion type caused at the cutting base, the values were statistically similar. However, when analyzing the percentage values, it should be noted that the use of the wedge lesion increased rooting by approximately $8 \%$ and $2.5 \%$ compared with the bevel type and horizontal type of lesions (Table 2).

Concerning apical cuttings, there was a statistically significant difference between the wedge and horizontal lesions compared with the bevel type, with the latter showing lower rooting percentage values. Although, not statistically significant, the wedge lesion had 5.5\% more rooting than the control. The wedge lesion showed a superior rooting percentage, and there was no statistically significant

Table 1 - Percentage of podocarp cuttings with callus treated with different methods of application IBA.

\begin{tabular}{lc}
\hline Methods of application & Callus cutting (\%) \\
\hline Solution & $3.96 \mathrm{~b}$ \\
Talc & $1.82 \mathrm{a}$ \\
\hline
\end{tabular}

${ }^{*}$ Means followed by the same lower-case letter do not differ in the column by the Tukey test, at $5 \%$ probability of error. Data transformed by square root of $\mathrm{X}+1.0$. difference between using basal or apical cuttings for this type of lesion. However, by using basal cuttings, it was possible to have $10 \%$ more rooting.

WENDLING et al. (2016) studied araucaria cuttings (Araucaria angustifolia) and found that apical cuttings rooted faster and showed better characteristics for the evaluated parameters. The authors discussed that endogenous auxin concentrations could explain this result, since the hormone is produced by the apical meristematic tissues and is taken to the cutting base where, together with other substances, it acts in rhizogenesis induction.

SOUZA et al. (2015) reported a significant difference when using apical and basal cuttings for hibiscus (Hibiscus rosa-sinensis L.) propagation, obtaining average values for apical and basal cuttings of 3.3 and $75 \%$, respectively. This is because basal cuttings present a semi-woody constitution compared with the apical part, thus resulting in greater tissue maturity anda greater capacity to provide the carbohydrates necessary for root growth. The most suitable cutting type can vary among species and/ or the cultivar used, since these can differ in the chemical composition variations of the tissues along the branch. Therefore, cuttings from different parts tend to differ in rooting. For example, apical cuttings are closer to the auxin synthesis site and have less tissue differentiation, which usually facilitates adventitious root formation (RINALDI et al., 2017; CUNHA et al., 2015).

Results obtained help to clarify issues of vegetative propagation of this importantlandscape 
Table 2 - Percentage of rooting of podocarp cuttings with different lesions at the base of the cut and types of cut.

\begin{tabular}{lcc|}
\hline Types of CUT & \multicolumn{2}{c}{ Withdrawals from cuttings } \\
\hline & Basal & Apical \\
Wedge & $91.11 \mathrm{Aa}$ & $82.22 \mathrm{Aa}$ \\
Bevel & $84.44 \mathrm{Aa}$ & $51.11 \mathrm{Bb}$ \\
Horizontal & $88.89 \mathrm{Aa}$ & $77.78 \mathrm{Aa}$ \\
\hline
\end{tabular}

${ }^{*}$ Means followed by the same lower-case letter do not differ in the column by the Tukey test, at $5 \%$ probability of error.

species. From this study, future research can be conducted to improve propagation, for example, on the use of talc and different IBA concentrations, as talc provided a lower percentage of calloused cuttings.

\section{CONCLUSION}

Basal cuttings of $P$. macrophyllus with wedge lesions at the base and treated with IBA in solution at a concentration of 550 $\mathrm{mg} \mathrm{L}^{-1}$ can be used to obtain good results for asexual propagation.

\section{DECLARATION OF CONFLICT OF INTEREST}

We have no conflict of interest to declare.

\section{ACKNOWLEDGMENTS}

This study was financed in part by the Coordenação de Aperfeiçoamento de Pessoal de Nível Superior (CAPES), Brazil.

\section{AUTHORS' CONTRIBUTIONS}

All authors contributed equally for the conception and writing of the manuscript. All authors critically revised the manuscript and approved of the final version.

\section{REFERENCES}

CIRIELLO, E.; MORI, E. S. Rooting of guanandi (Calophyllum brasiliense CAMBESS) cuttings using indole-butyric acid. Cerne, v.21, p.641-647, 2015. Available from: <https://www.scielo.br/ scielo.php?script $=$ sci_arttext\&pid=S0104-77602015000400641 $>$. Accessed: Oct. 22, 2019.doi: 10.1590/01047760201521041803.

CORDEIRO, I. M. et al.Rooting of juvenile cuttings of Bertholletia excelsa under different concentrations of indolebutyric acid. Agrociência, v.50, p.227-238, 2016. Available from: <http:// www.scielo.org. $\mathrm{mx} / \mathrm{sciel}$.php? script $=\mathrm{sci}$ arttext\&pid $=\mathrm{S} 1405$ 31952016000200227\&lng=es\&tlng=en>. Accessed: Oct. 22, 2019. doi: $10.1590 / 01047760201521041803$.

CUNHA, A.L.B. et al. Vegetative propagation of Piper hispidum Sw. Cuttings on different substrates. Revista Brasileira de Plantas
Medicinais, v.17, p.685-692, 2015.Available from: <http://www. scielo.br/pdf/rbpm/v17n4s1/1516-0572-rbpm-17-4-s1-0685.pdf $>$. Accessed: Oct. 22, 2019. doi: 10.1590/1983-084X/14_113.

DOBNER, M. D. et al. Assexual propagation of Cupressus lusitanica and Cryptomeria japonica: the challenge of genetic rescuing adult trees. Revista Scientia Forestalis, v.46, p.5363, 2018. Available from: <https://www.ipef.br/publicacoes/ scientia/nr117/cap05.pdf $>$. Accessed: Oct. 22, 2019. doi: 10.18671/scifor.v46n117.05

ENRIGHT, N. J.; JAFREÉ, T. Ecology and distribution of the malesian podocarps.In: TURNER, B. L.\& CERNUSAK, B. L. A. (ed.). Ecology of the Podocarpaceae in tropical forests. Washington: Scholarly press, 2010. p.57-77.

FERREIRA, D. F. Sisvar: a computer statistical analysis system. Ciência e Agrotecnologia, v.35, p.1039-1042, 2011. Available from: <http://www.scielo.br/scielo.php?pid=S1413$70542011000600001 \&$ script $=$ sci arttext\&tlng $=\mathrm{pt}>$. Accessed: Oct. 22, 2019. doi: $10.1590 /$ S1413-70542011000600001

HARTMANN, H. T. etal. Plant propagation: principles and practices. 9.ed. New Jersey: Prentice-Hall, 2018. 1024p.

HOSSAIN, M. A. et al. Propagation of an endangered gymnosperm tree species (Podocarpus neriifolius D. Don.) by stem cuttings in non-mist propagator. Pertanika Journal of Tropical Agriculture Science, v.42, p.237-250, 2019.Available from: <file://C:/Users/ Utente/Downloads/16JTAS-1409-2018\%20(1).pdf $>$. Accessed: Oct. 22, 2019.

HUNT, M. A. et al. Indole-3-butyric acid accelerates adventitious root formation and impedes shoot growthof Pinus elliottiivar. elliottiix P. caribaea var. hondurensis cuttings. New Forests, v.41, p.349-360, 2011. Available from: <https://link.springer.com/ article/10.1007/s11056-010-9227-7>. Accessed: Oct. 22, 2019. doi: 10.1007/s11056-010-9227-7.

LORENZI, H.; SOUZA, H. M. Plantas ornamentais no Brasil: arbustivas, herbáceas e trepadeiras. 3. ed. Nova Odessa: Plantarum, 2013. 1120p.

MARINHO, L. C. et al. Flora da Bahia: Podocarpaceae. Sitientibus.Série Ciências Biológicas, v.16, p.1-5, 2016. Available from: $<$ http://periodicos.uefs.br/index.php/ sitientibusBiologia/article/view/1089/843>. Accessed: Oct. 22, 2019. doi: $10.13102 / \mathrm{scb} 1089$.

PEREIRA, M. O. et al. Rooting of Tibouchina moricandiana var. vinacea cuttings as a function of application form and IBA concentrations. Revista de Ciências Agroveterinárias, v.14, p.210-216, 2015. Available from: <https://core.ac.uk/ download/pdf/234149672.pdf $>$. Accessed: Oct. 19, 2019. doi: $10.5965 / 223811711432015210$.

PROPLANT. PRODUTORES DE PLANTAS. Associação dos produtores de plantas ornamentais de Corupá. Available from: $<\mathrm{http}: / /$ www.proplant.com.br/>. Accessed: Oct. 19, 2019.

RAGONEZI, C. et. al. Adventitious rooting of conifers: Influence of physical and chemical factors. Trees, v.24, p.975-992, 2010. Available from: <https://link.springer.com/article/10.1007/s00468-010-04888>. Accessed: Oct. 15, 2019. doi: 10.1007/s00468-010-0488-8.

RINALDI, A. R. et al. Stem cuttings and substrates in Dovyalis asexual propagation. Comunicata Scientiae, v.8, p.587-595,

Ciência Rural, v.51, n.9, 2021. 
2017. Available from: <https://comunicatascientiae.com.br/ comunicata/article/view/1986>. Accessed: Oct. 18, 2019.doi: 14295/CS.v8i4.1986.

SALVADOR, T. L. et al. Rooting cuttings of sugar apple (Annona squamosa L.) with indolebutyric acid. Revista Brasileira de Fruticultura, v.36, p.310-314, 2014.Available from: $<$ http://www. scielo.br/pdf/rbf/v36nspe1/v36nspe1a37.pdf $>$. Accessed: Oct. 18, 2019. doi: 10.1590/S0100-29452014000500037.

SILVA A. et al. Rooting of stem cuttings of ixora. Ornamental Horticulture, v.21, p.201-208, 2015. Available from: <https:// ornamentalhorticulture.emnuvens.com.br/rbho/article/ view/656/578>. Accessed: Oct. 18, 2019.

SOUZA, R. R. et al. Vegetative propagation of hibiscus with different types of cuttings and IBA concentrations. Comunicata Scientiae, v.6, p.291-296, 2015. Available from: <https://www. comunicatascientiae.com.br/comunicata/article/viewFile/679/346>. Accessed: Oct. 18, 2019. doi: 10.14295/CS.v6i3.679.

TOGNON, G. B.; CUQUEL, F. L. Ornamental potencial of Baccharis milleflora and Baccharis tridentate as cut foliage. Ciência Rural, v.46, p.70-75, 2016. Available from: $<$ https://www. scielo.br/pdf/cr/v46n1/1678-4596-cr-0103 8478cr20150392.pdf>. Accessed: Oct. 18, 2019. doi: 10.1590/0103-8478cr20150392.
VIEIRA NETO, J. et al. Performance of clonal olive tree (Olea europaea) gardens in successive cuts aiming cutting propagation. Cerne,v.17,p.117-122,2011.Availablefrom: $<$ https://www.scielo.br/ scielo.php?script=sci_arttext\&pid=S0104-77602011000100014>. Accessed: Oct. 18, 2019. doi: 10.1590/S0104-77602011000100014.

VILLA, F. et al. Performance of substrates in rooting capacity of olive tree cuttings. Revista de Ciências Agroveterinárias, v.16, p.95-101, 2017. Available from: <https://revistas.udesc.br/index. php/agroveterinaria/article/view/223811711622017095/pdf $>$. Accessed: Oct. 18, 2019. doi: 10.5965/223811711622017095.

WENDLING, I. et al. Rooting of Araucaria angustifolia: types of cuttings and stock plants sex.Revista Árvore, v.40, p.10131021, 2016.Available from: <https://www.scielo.br/scielo. php?script $=$ sci arttext\&pid $=\mathrm{S} 0100-67622016000601013>$. Accessed: Oct. $1 \overline{8}, 2019$. doi: 10.1590/0100-67622016000600006.

YAMAMOTO, L. Y. et al.Cutting rooting of Psidium guajava L. 'Século $\mathrm{XXI}$ ' guava treated with indolebutyric acid with talc and alcohol as a vehicle. Ciência Rural, v.40, p.1037-1042, 2010. Available from: <http:/www. scielo.br/scielo.php?script=sci_arttext\&pid=S0103-84782010000500006>. Accessed: Oct. 21, 2019. doi: 10.1590/S0103-84782010000500006.

ZANÃO, M. P. C. et al. Withdrawal of region cutting and substrate in propagation vegetative pot of roseira. Ornamental Horticulture, v.22, p.58-62, 2016. Available from: $<$ https://ornamentalhorticulture.emnuvens. com.br/rbho/article/viewFile/785/626>. Accessed: Oct. 19, 2019. 